\title{
S14 - Buenas prácticas de manufactura en Bancos de Leche Humana de la Red Nacional de Bancos de Leche Humana de Guatemala
}

\author{
Evany Guzmán, Alejandra Sempé, Carlos Guzmán, Gerardo Arroyo \\ Escuela de Química Biológica, Facultad de Ciencias Químicas y Farmacia, \\ Universidad de San Carlos de Guatemala.
}

*Autor al que se dirige la correspondencia: gerarroyo@gmail.com

\section{Resumen}

T a presente investigación tuvo como objetivo verificar el cumplimiento de las Buenas Prácticas de Manufactura (BPM) en siete Bancos de Leche Humana (BLH) de la Red Nacional, estableciendo las condiciones y recomendaciones de infraestructura, equipos, procesos, procedimientos y personal para el mejoramiento de los BLH con el fin de asegurar su adecuado funcionamiento. Se realizó una auditoría diagnóstica evaluando las condiciones de BPM en los BLH de la Red Nacional utilizando la ficha de inspección de BPM del Reglamento Técnico Centroamericano (RTCA) 67.01.33:06. La información recolectada se analizó mediante estadística descriptiva calculando un valor sobre 100 puntos, con el fin de valorar las condiciones y realizar un informe donde se detallaron las deficiencias y recomendaciones para mejorar el sistema y garantizar leche humana inocua, que fue entregado a cada BLH evaluado. Los BLH del Hospital General San Juan de Dios (HGSJD) y del Hospital Regional de Antigua Guatemala obtuvieron punteos que indica que poseen buenas condiciones y son aptas para procesar la leche humana; los BLH del Hospital Regional de Cobán y Puerto Barrios con regulares condiciones con correcciones para el proceso con riesgo de contaminación; los BLH de Santa Rosa y Totonicapán con condiciones ineficientes que urge corregir y el BLH de Zacapa obtuvo punteo que indica condiciones inaceptables que sugieren considerar el cierre. La mayoría de BLH posee deficiencias claras, sin embargo, son aptos para procesar la leche humana con resultados inocuos con excepción del BLH de Zacapa.

Palabras claves: Leche Humana, Banco de Leche de Humana, RTCA, BPM, Red Nacional de Bancos de Leche Humana

\section{Abstract}

$\mathrm{T}$ he main goal of this project was to verify the compliance with Good Manufacturing Practices (GMP) in seven Human Milk Banks (HMB) of the National Network, establishing the conditions and recommendations of infrastructure, equipment, processes, procedures and personnel for the improvement of HMB in order to ensure their proper functioning. A diagnostic audit was conducted evaluating conditions of GMP in HMB of the National Network; the collected data was analyzed using descriptive statistics and calculating a value over 100 points based on an inspection questionnaire for GMP of RTCA 67.01.33: 06, with the purpose of establish the conditions and making a report where deficiencies were detailed and recommendations to improve the system and keep safe human milk, that was delivered to each HMB. Human milk banks located at Hospital General San Juan de Dios (HGSJD) and Hospital de Antigua Guatemala obtained a score indicating that possess good condition and are suitable for processing human milk; HMB of the Hospital Regional de Coban and Puerto Barrios showed regular condition with corrections to the process and risk of contamination; HMB of Santa Rosa and Totonicapán with inefficient conditions that needed to be corrected with urgency and HMB of Zacapa showed conditions indicating unacceptable processes considering immediate closing. Most HMB had clear deficiencies however, are apt to process the human milk safey, except HMB Zacapa which was recommended for closure.

Keywords: Human Milk, Human Milk Bank, RTCA, GMP, National Network of Human Milk Banks 